\title{
FROM EXCESS TO SHORTAGE - RECENT DEVELOPMENTS IN THE DANISH LABOUR MARKET
}

\author{
TORBEN M. ANDERSEN
}

CESIFO WORKING PAPER No. 933

CATEGORY 4: LABOUR MARKETS

APRIL 2003

Presented at CESifo Conference on Unemployment in Europe:

Reasons and Remedies, December 2002

An electronic version of the paper may be downloaded

- from the SSRN website: Www.SSRN.com

- from the CESifo website: www.CESifo.de 


\title{
FROM EXCESS TO SHORTAGE - RECENT DEVELOPMENTS IN THE DANISH LABOUR MARKET
}

\begin{abstract}
The Danish labour market has undergone a remarkable change during the 1990s with a reduction of the unemployment rate from about 12 per cent in 1993 to less than 6 per cent at the turn of the century. This reflects both a turn in the business cycle but also structural changes related to shifts in labour market policies. The focus of labour market policies has been changed from passive measures towards more active measures and there has also been important changes in the unemployment insurance system. This paper offers an overview of the developments in the Danish labour market during the 1990s, and reviews the major policy shifts, as well as possible explanations of the remarkable reduction in unemployment.
\end{abstract}

JEL Code: J3, J6.

\author{
Torben M. Andersen \\ University of Aarhus \\ Department of Economics \\ Building 350 \\ Universitetsparken \\ 8000 Aarhus $G$ \\ Denmark \\ tandersen@econ.au.dk
}

Comments and suggestions from participations and the discussant Jan van Ours at the CESifo/Yrjö Jansson Foundation conference on Unemployment in Europe, December 6-7, 2002, as well as from Jan V. Hansen are gratefully acknowledged. 


\section{Introduction}

The Danish labour market has undergone a remarkable change during the 1990s. At the start of the decade the policy debate was still dominated by the concern of how to adapt to long-lasting unemployment, and policy initiatives were mainly passive in nature based on the view that there was an excess of labour supply relative to the job creation potential of the economy. By the turn of the century the debate is focused on how to expand labour supply so as to prevent overheating of the labour market and to prepare for the demographic changes which in the absence of reforms will lead to a decline in labour supply. The current policy debate is thus dominated by reform proposals to strengthen the incentives underlying labour supply in all its dimensions (hours, participation and retirement etc.).

Figure 1: Unemployment rate 1948-2001

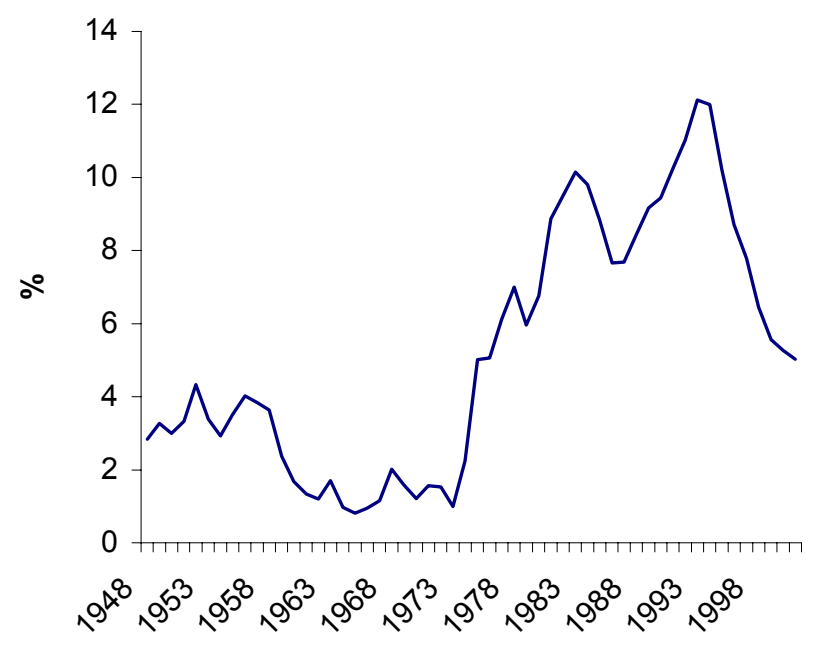

Note: Number of unemployed as a percentage of the labour force

Source: ADAM-databank, Statistics Denmark 
As many European countries, Denmark experienced an increase in unemployment in the mid 1970s. The tendency to increasing unemployment was interrupted in the mid 1980s during an upswing in the Danish economy, but it began to pick up again in the latter half of the 1980s. The unemployment problem has thus been persistent, and the registered unemployment rate peaked at $12 \%$ in 1993 . Subsequently, it has been steadily decreasing, and currently the rate has been stable for a couple of years at a level slightly below 5\%, cf. Figure 1 . In early 2003 there is some tendency to an increase in unemployment reflecting a less favourable business cycle situation.

The development in unemployment has taken place against the background of quite different levels of nominal wage and price inflation, cf. Figure 2. During the late 1970s and the early 1980s inflation was high, but a disinflationary policy initiated by the re-launch in 1982 of a fixed exchange rate policy combined with a tight income policy brought inflation down. In recent years inflation has been stable at a level around 2-3\%. It is particularly noteworthy, cf. Figure 2, that nominal wage increases have been stable over the period in which unemployment has been reduced.

\section{Figure 2: Wage and price increases}

(a) Wage and price inflation

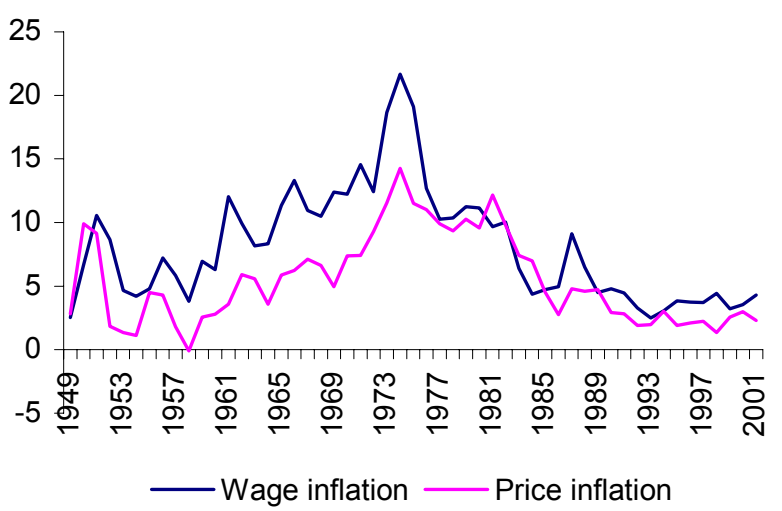

(b) Real wage increases

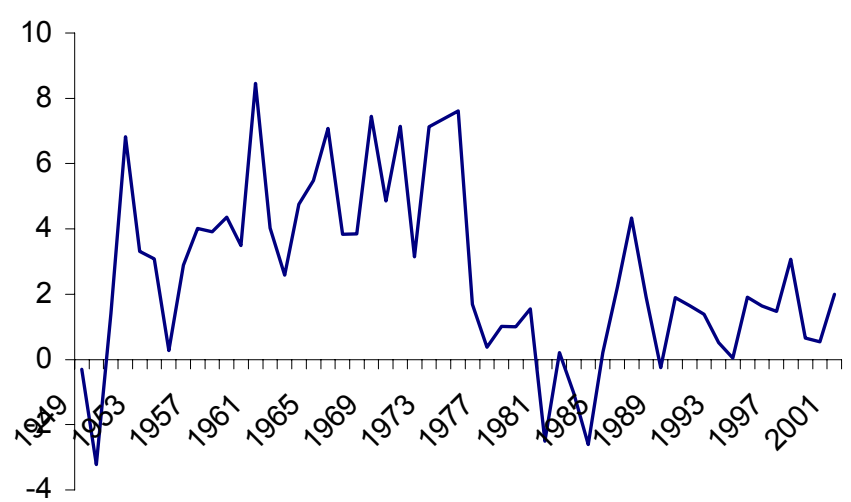

Source: ADAM-databank, Statistics Denmark

Despite the substantial difference in nominal wage increases over the past decades real wages development has been fairly steady and the period since 1970 can in terms of real wage growth be divided into three periods. The period 1960-1975 had a real wage growth of 5.5\%, from 1976 to 1992 it was only $0.8 \%$, and over the period 1993-2001 it has been $1.9 \%$. It is worth noting that inequality in Denmark has been roughly unchanged over the period in which the unemployment rate has varied substantially (see Det Økonomiske Råd 2001). This can both be taken as a reflection of how the Danish welfare model works, and the political constraints which have been imposed on the policies pursued.

The aim of this paper is to consider the reason for the sharp reduction in unemployment, and the fact that it has been possible to maintain a lower unemployment rate without inducing wage increases. To set the scene for the subsequent discussion of changes in the Danish labour market during the 1990s, it is useful to bring the development in perspective by briefly reviewing the developments and policy views prevailing in the past. From practically full 
employment during the 1960s unemployment rose to double digit figures in the mid 1970s and this situation turned out to be very persistent, cf. Figure 1. Various measures were launched during the late 1970s and early 1980s including devaluations and a twist strategy for aggregate demand management aiming at curtailing private demand and expanding public demand to direct demand towards domestic producers and thereby improving both the unemployment and the current account situation. However, this line of policy did not succeed in reducing the unemployment problem (nor any other major macroeconomic policy concern). During the early 1980s there was a shift towards a fixed exchange rate policy accompanied by income policy and a tight fiscal policy (see Andersen (1994)). A hike in domestic demand initiated a boom which also brought unemployment down, cf. Figure 1. However, a wage hike in 1987 (see figure 2a) suggested that structural problems prevented a lasting reduction in the unemployment rate, and subsequently the unemployment rate rose again. This started a sevenyear-long period with low growth and high and increasing unemployment, which was terminated by the policy shift in 1993/94 (see below).

Throughout there has been broad political support to the view that the unemployment problem should not be solved by a retrenchment of welfare policies via reductions in unemployment benefits and social assistance. On the contrary, various policy initiatives have been taken to ensure income maintenance for the unemployed. As a consequence the rules for benefit duration were extended and participation in various so-called job-offer schemes could be used to re-qualify for unemployment benefits. Other measures were introduced to reduce labour supply, most important was the early retirement scheme launched in 1979. In the late 1980s and early 1990s an increasingly dominating view in the public debate was that "we have to learn to live with an excess of labour".

After a change in government in 1992 a new policy was launched which in retrospect can be interpreted as having followed a two-handed approach, although the policy strategy developed over time. Part of the shift was an expansionary fiscal policy to boost growth and pave the way for a reduction in unemployment. The other part was a shift in labour market policy which implied that more passive policies which had been pursued in the past were changed in a more active direction. In particular the incentive structure was changed, although there have been few direct cuts in transfer payments and the like (see below).

With the outset in this background this paper attempts to provide an overview of the developments in the Danish labour market during the 1990s. It reviews the major policy shifts during the 1990s, and discusses possible explanations which have been offered of the remarkable reduction in unemployment.

The paper is organized as follows: Section 2 provides a few facts on labour market developments in Denmark, and section 3 turns to a discussion of the role of business cycle and structural factors for unemployment. Section 4 offers a detailed discussion of labour market policies with particular focus on the implications of the shifts from passive to more active measures. Wage formation is addressed in section 5 which also considers the role of decentralization, mis-match and taxation. The implications of ageing and integration of immigrants for labour supply are briefly discussed in section 6, and section 7 gives a few concluding remarks.

\section{A few facts}

The Danish labour market is characterized by a relatively high labour force participation rate (76\% in 2001), and in particular the participation rate for women is high by international standards (71\% in 2001). There has been a trend decline in the participation rate for men (it 
was $95 \%$ in 1950), and a trend increase for women until the early 1990 s (reaching $72 \%$ in 1990). Over the years there has been a trend decline in working hours (average working hours were above 2300 hours per year in 1950, and below 1700 in 2001), and the retirement age has also dropped (currently the average retirement age is about 61 years, whereas the official pension age is 65).

Some summary statistics on the developments in the Danish labour market are given in Table 1. It is seen that female and youth unemployment went up during the high unemployment period, which also had an increase in long-term unemployment in particular for unskilled. The reduction in unemployment has reversed these trends.

Table 1: Key labour market facts 1970-2000

\begin{tabular}{|l|l|l|l|l|l|l|l|}
\hline & 1970 & 1975 & 1980 & 1985 & 1990 & 1995 & 2000 \\
\hline $\begin{array}{l}\text { Registered } \\
\text { unemployment } \\
\text { rate (a) }\end{array}$ & 1.2 & 5.0 & 6.8 & 9.1 & 9.7 & 10.4 & 5.4 \\
\hline $\begin{array}{l}\text { Youth } \\
\text { unemployment } \\
\text { (b) }\end{array}$ & 4.0 & 16.2 & 10.6 & 10.2 & 10.6 & 8.5 & 3.1 \\
\hline $\begin{array}{l}\text { Female } \\
\text { unemployment } \\
\text { rate }\end{array}$ & 0.5 & 3.9 & 7.5 & 11.0 & 11.3 & 12.0 & 6.3 \\
\hline $\begin{array}{l}\text { Long-term } \\
\text { Unemployment } \\
\text { (c) }\end{array}$ & na & na & 28 & 32 & 35 & 35 & 25 \\
\hline
\end{tabular}

Notes: a) Registered unemployed as share of labour force, b) age group 16-24 years, c) fraction of unemployment due to number of unemployed for at least $80 \%$ of the working year.

Source: Danmarks Statistik

In an extended welfare state as the Danish with strong universal elements in welfare policies it is important to consider the unemployment problem from two angles, namely, the number of people effectively available for the labour market, and the number of people relying on income transfers from the public. The two need not coincide since the use of passive measures in labour market policies may imply that those being entitled for welfare payments of one form or another are not necessarily available for the labour market. Figure 3 shows that this distinction is not trivial for Denmark since there has been a large and systematic difference between the two. The figure plots the registered unemployment rate as well as a measure for search unemployment (those actively searching for jobs and ready to work, cf. ILO definition) and a gross measure for unemployment (unemployed plus people in activation and early retirement schemes from unemployment). The figure brings out two important features. First, search unemployment has generally been below the registered unemployment rate suggesting that the latter does not provide a reliable indicator of the slack in the labour market, and that some are claiming unemployment benefits without being actively searching for jobs. Second, the gross unemployment rate is much larger than the registered rate indicating that the implications of unemployment for public finances are much larger than the official unemployment figures suggest. 


\section{Figure 3: Search and gross unemployment}

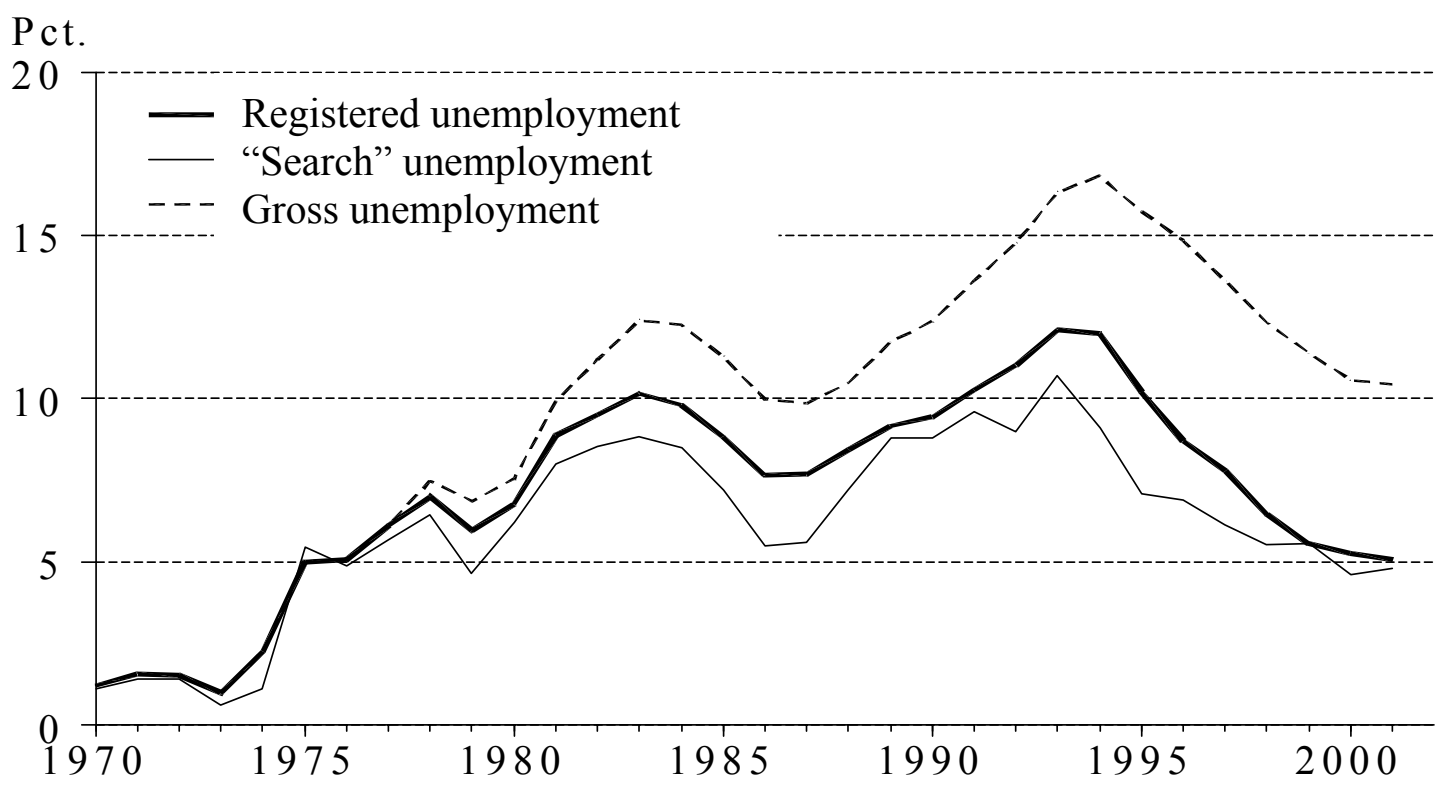

Source: Det Økonomiske Råd

\section{Business Cycle vs Structural Components}

The development in the labour market during the 1990s has been accompanied by a business cycle upturn. The average growth rate for GDP in the period 1993-2001 was 2.5\% while it only was $0.25 \%$ for the period $1987-1993$ The level of unemployment prevailing in the early part of the 1990s undoubtedly had a non-trivial business cycle component, that is, it was to be expected that a turn in the business cycle would be able to reduce unemployment. However, structural improvements are also important. To see this it is interesting to compare the developments during the 1980s and the 1990s, which get close to a controlled experiment of the effects of substantial increases in aggregate demand ${ }^{2}$. In the first part of the 1980s there was also a business cycle upturn, growth rates soared and unemployment started to fall. However, the upturn was constrained by labour shortage in specific areas and wage increases reached almost $9 \%$ in 1987 well beyond the level consistent with the fixed exchange rate policy. Since growth in domestic demand was high, there is no doubt that various supply constraints played a role. This is directly seen from the fact that import growth peaked and the current account turned into a record deficit of 5.3\% of GDP in 1986. This suggested binding structural problems in the labour market preventing unemployment from falling below a level of 8-9\%. However, during the recent upswing it has been possible to bring unemployment below this level without igniting wage increases. This indicates that structural unemployment has been reduced in the 1990s.

\footnotetext{
${ }^{2}$ Both periods were characterized by substantial increases in domestic demand. The aggregate demand increase in the 1980s boom was slightly more rapid/strong than the one in the 1990s. However, the two periods also differ in a number of other respects including the current account position, public deficits, inflation etc.
} 
It is very difficult to disentangle the business cycle and the structural component in the reduction in unemployment for several reasons. First, the policy changes over the period can be interpreted as following a two-handed strategy involving both demand and supply measures. Initially the period was kicked off by an expansionary fiscal policy ${ }^{3}$, and subsequently when unemployment started to decrease the labour market policy was in several steps tightened (see below). In political economy terms there is no doubt that these changes in labour market policy were only possible because unemployment was falling. The measures were motivated by the fact that it was possible to do something about the unemployment problem and that it was important not to repeat the experience from the mid 1980s.

Various measures of the structural unemployment rate have been made (see e.g.

Finansministeriet (2002a)). These measures suggest that structural unemployment peaked at $11 \%$ in 1993 and subsequently fell to a level of $5-6 \%$.

In a recent estimate (Det Økonomiske Råd, 2002) it is suggested that the reduction in unemployment from 1993 to 2001 of 7 percentage points can be decomposed into 1-1.5 percentage points due to passive measures transferring unemployed to other schemes (early retirement, paid leave schemes etc.), 2-3 percentage points can be attributed to the business cycle component, and 2-3 percentage points to structural improvements.

However, it should be noted that measures of structural unemployment can be difficult to interpret. First, the estimated structural unemployment rates follow a smoothened version of the actual unemployment rate, and does not relate the changes to any underlying structural variables, i.e. the changes in the structural unemployment rate are basically unaccounted for. Second, it is very hard to envision structural changes of such strength that the structural unemployment rate went up by several percentage points from 1987 to 1990 . The only possible candidate seems to be a depreciation of human capital, but it is hard to reconcile this explanation with the subsequent sharp reduction in unemployment.

The presence of substantial business cycle components in the reduction in unemployment and the fact that unemployment has been persistently high suggest that the self-equilibrating mechanisms in the labour market work very sluggishly. Attempts to identify the persistence generation mechanisms suggest that substantial inertia is present in the adjustment process (see e.g. Andersen and Hylleberg (2000)). Both nominal and real sources of inertia are found to be important, but the former seems to be quantitatively most important. However, the adjustment failures are not strong enough to support the interpretation that the deteriorating labour market performance is due to a sequence of adverse shocks in combination with substantial inertia. Accordingly, to account for the persistence of unemployment it is necessary to take structural factors into account. A pertinent question is whether the extended arrangements of the welfare state have been successful in ensuring a very high degree of income insurance (reflected in inequality being unaffected by the rise in unemployment), but at the cost of a worsening of the incentive structure so as to cause an increase in the structural unemployment rate.

\section{Labour market policies}

During the 1990s a number of labour market reforms have been initiated. Whereas the initial phase was characterized by a continuation of passive policies via e.g. a paid leave scheme (later abolished), the policy gradually changed to put more emphasis on active measures with

\footnotetext{
${ }^{3}$ Estimates of the expansionary effects of discretionary fiscal policy changes shows that it added about 0.7 percentage point to growth in 1993 and 1994, Finansministeriet (2000).
} 
the specific aim of reducing the possibilities of passively claiming unemployment benefits, and to enhance the possibilities for unemployed to find regular jobs.

\subsection{Unemployment benefits}

The Danish unemployment insurance scheme is by international standards fairly generous. The average replacement ratio is some $60 \%$, and the entitlement period has in the past - despite various statutory limits - effectively been open-ended, and eligibility could easily be obtained (via education or work for 6 months). The benefits are calculated as $90 \%$ of previous earnings, but there is a maximum benefit level (currently constituting about $50 \%$ of average pay for ordinary wage earners). This implies that the replacement rate is highest for low wage groups and declines with wage income. Membership of an unemployment insurance scheme is voluntary, and members pay a fixed contribution. Membership is therefore closely correlated with unemployment risk (see Parssons et al. (2002)). Marginal expenses in the unemployment insurance system are covered by the public sector implying that in periods with high unemployment the public financial contribution has been large. In the past there has been no severance pay in the Danish system. Denmark has therefore had an internationally high rate of short-term unemployment. Hiring and firing rules are flexible (Nicoletti et al. (2000)). A key political premise underlying the labour market reforms during the 1990s has been that there should be no direct reductions in transfer payments. The political constraint has therefore been to improve the incentive structure without undertaking a retrenchment of key welfare state arrangements. Still substantial tightening of the unemployment scheme have been made, and the Danish case is thus interesting in showing a possible route for labour market reforms which does not jeopardize basic welfare state objectives.

The duration of the entitlement period for unemployment benefits has been radically reduced. In 1993 the duration period was officially 7 years (although in practice it could be prolonged by participation in job-offer schemes), and in a sequence of reforms it has now been reduced to 4 years, see Figure 3. At the same time passive collection of unemployment benefits is no longer possible. The current policy ${ }^{4}$ is based on the so-called "rights and obligations" principle implying that individuals have a right to compensation for loss of income, but also an obligation to take action, at the same time society has an obligation in trying to improve the situation of the individual, and therefore a right to impose certain requirements for entitlement for benefits. The current scheme implies that the "passive" period on unemployment benefits cannot exceed one year, and that the "activation period" should be initiated no later than one year after having become unemployed, and constitute $75 \%$ of the unemployment benefit duration period. While maintaining the unemployment benefits unchanged, the introduction of such mandatory activation schemes has effectively influenced the incentives to search for regular jobs, and introduced obstacles to reduce misuse of the system (by e.g. voluntary unemployed or people working in the shadow economy).

\footnotetext{
${ }^{4}$ A recent reform has implied that the rules will be interpreted more flexible as of from July 2003, see also Figure 4.
} 


\section{Figure 4 Changes in the unemployment system - benefit and "activation" period}

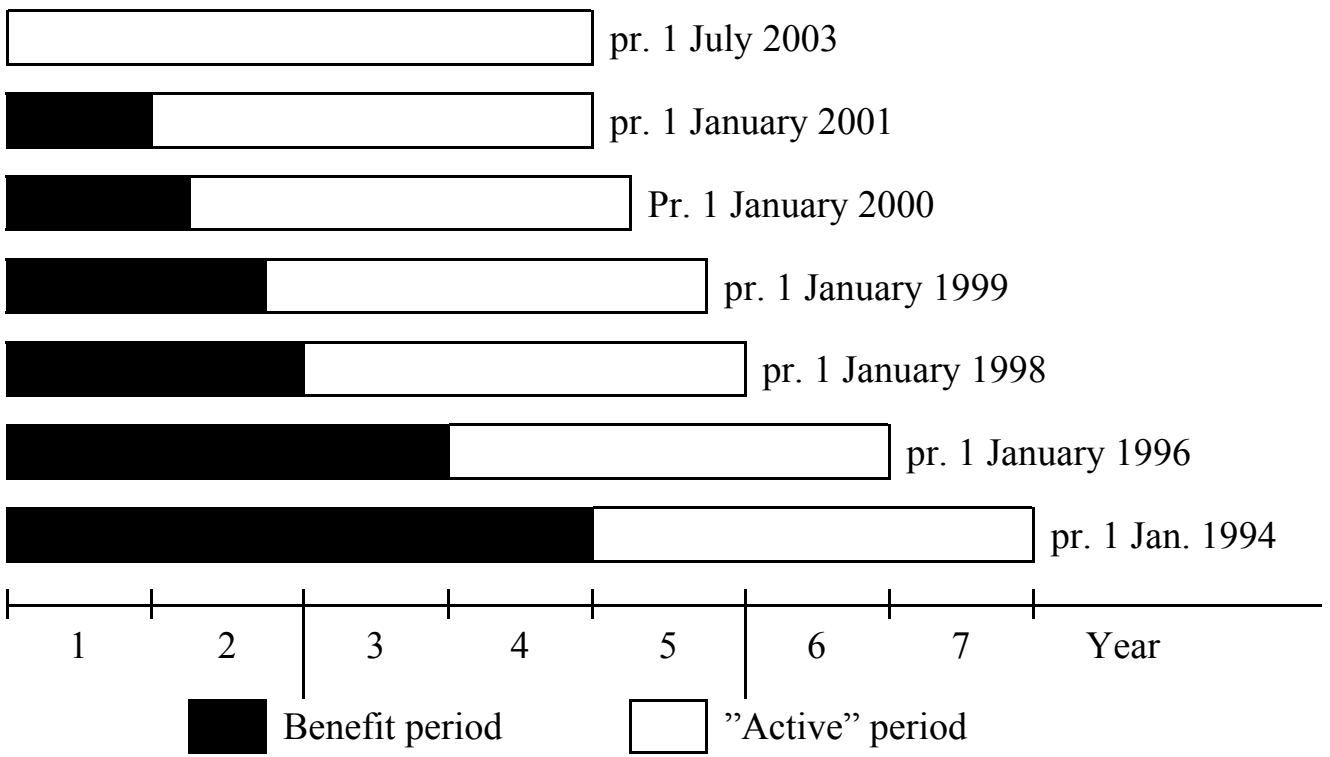

Note: The "right and obligation principle" in the "active" period was introduced in 1995. As of 2003 there is no distinction between the passive benefit period and the activation period.

Source Finansministeriet (1999), Arbejdsministeriet (2000) og Beskæftigelsesministeriet (2002).

Entitlement to unemployment benefits now requires regular work of a duration of one year within the last three years (previously six months within the last three years). Importantly, participation in activation schemes does not qualify (since 1994) for renewed entitlement to unemployment benefits. If the benefit period expires without having found a regular job, the person will have to rely social benefits (means tested on the basis of among other things the family situation). While the unemployment benefits are flat during the unemployment period, the combination of the unemployment benefit scheme and social assistance implies that the individual faces a step-wise profile of compensation as illustrated in Figure 5. As of 1998 the "right and obligations" principle has also been extended to the social benefit scheme. It is readily seen from Figure 5 that the economic incentives for low income groups moving from unemployment to work are small (irrespective of whether unemployment benefits or social benefits are claimed), whereas the incentive for higher income groups is larger. Several studies have confirmed that for low income groups the economic incentive to work can be small or even absent (taking into account transport costs and child care), which is the net result of the taxation system (see below) and the design of the welfare system (See Finansministeriet (2002b) and Pedersen and Smith (2002)).

Figure 5: Duration dependence: Unemployment benefits and social assistance 

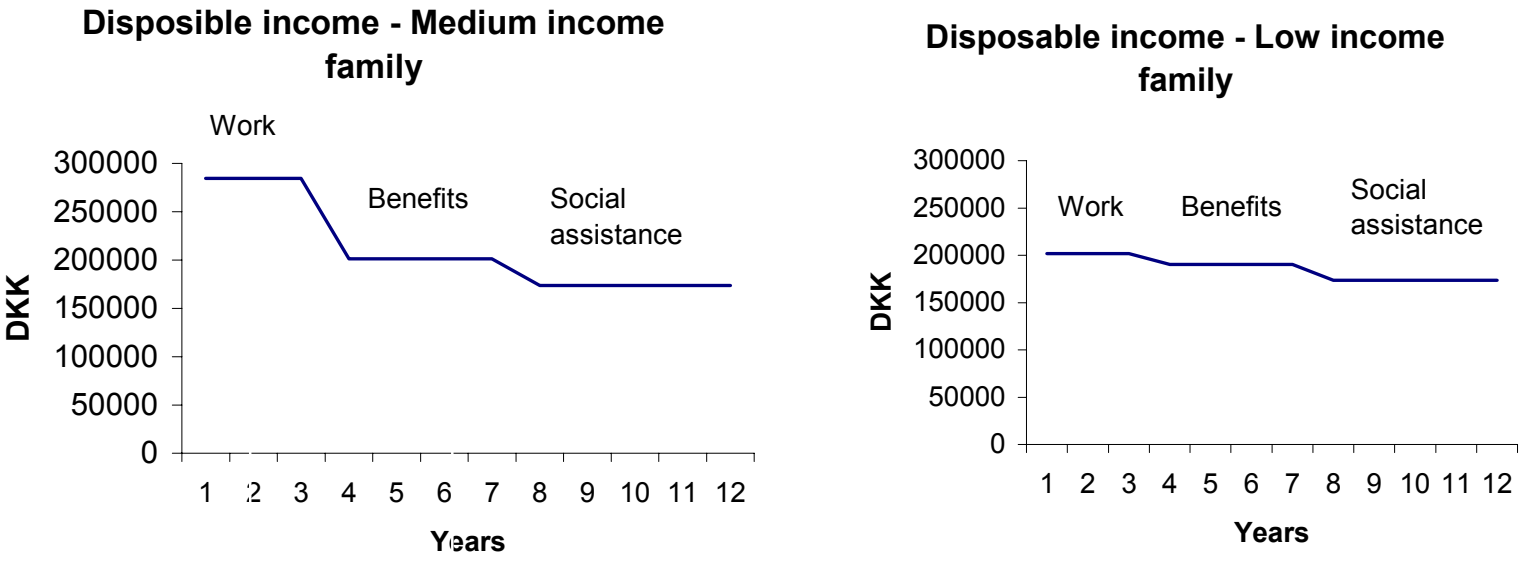

Note: Calculation made for families with one child.

Source: Det Økonomiske Råd (2002)

Despite unchanged statutory benefit levels the unemployment insurance scheme has thus been tightened substantially. It is difficult to summarize the many dimensions and changes of the system in a single measure, but Figure 6 gives an indication of the changes made by considering the development in the replacement rate for an average worker with and without the reforms. Two things are noteworthy. First, there is a trend decline in the replacement rate for the average worker due to the upper limit on unemployment benefits (which has not been following the trend in average pay). Second, the shortening of the duration period and the fact that entitlement cannot be regained by participation in activation measures has implied a substantial decrease in the effective replacement rate.

Figure 6: Replacement ratio for unemployment benefits

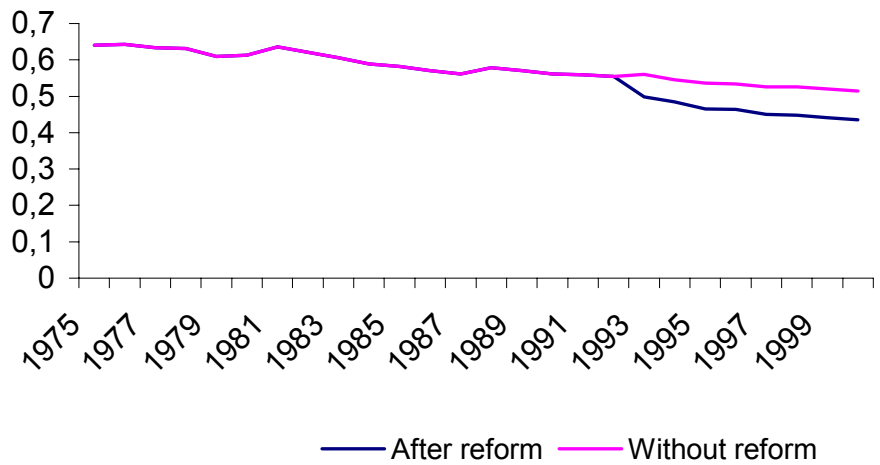

Note: The figures show the replacement ratio for an average worker as the present value of unemployment benefits and social assistance over a 20 year horizon, i.e. the option value of unemployment benefits and social assistance relative to the present value of average pay. Source: Det Økonomiske Råd (2002)

Since 1995 firms have been obliged to pay unemployment benefits for the first two days of an unemployment spell. The system with low hiring and firing costs gave firms and workers an 
incentive to exploit the unemployment insurance scheme in cases with short-run variations in labour demand. It is a fact that the incidence of short spells of unemployment is particularly high in Denmark, and that the re-employment propensity is high. Of those becoming unemployed in 1998 more than $40 \%$ were rehired by the same employer within a period of 26 weeks (Det Økonomiske Råd (2002)). This is suggestive that employers can use the unemployment insurance system as a buffer to cope with temporary variations in the need for workers.

There is one important exception to the rule that statutory benefit levels have not been changed, namely, the so-called "youth package" implemented in 1996. The reform was targeted persons below 25 and restricted the period for which unemployment benefits could be claimed to 6 months. This was a significant tightening since it previously was fairly easy to enter the unemployment insurance scheme by working 6 months and the unemployment compensation would exceed study support and wages in apprenticeships by a wide margin. The reform implies that an unemployed youth after the 6-month period would have to accept an education offer at $50 \%$ of unemployment benefits (equivalent to a study grant) (this scheme has been partially extended to all below 30 in the sense that in education activation they are entitled to a study grant and not unemployment benefits). One outstanding fact concerning the development in unemployment is that youth unemployment has come down from a peak level of $16 \%$ to about $3 \%$. The reform has undoubtedly contributed to this development.

\subsection{Activation}

An essential ingredient of the labour market policy has been so-called activation measures. Whereas such measures have been part of the labour market policy since 1978 the main purpose has in the past effectively been to provide a scheme to make it possible to regain the right to unemployment benefits. With the labour market reforms in the mid 1990s the activation schemes became an integral part of the "right and obligation" principle - the society offers income compensation, and the individual has the obligation to participate in activations schemes - passive collection of unemployment benefits should be prevented. As not above, an important part of the reform was that participation in an activation activity would not qualify for a new spell on unemployment benefits.

In principle one can think of various effects of activation. There is an incentive effect, since the value of unemployment benefits decreases when time consuming obligations are part of the package. This may induce some to search more actively for regular work (or give up work in the shadow economy), or leave the labour force because their value of leisure is high. This is a sorting effect implying that unemployment benefits become more targeted to those in real need. In principle this incentive or sorting effect could be achieved with any mandatory time consuming activity ${ }^{5}$. However, if the job prospects of unemployed can be improved by participation in activation this is a potential important additional effect. This could work via both a motivation effect (participating in activities motivating people to get back to regular work, or give them the habit of regular activities and the self-confidence needed), or a qualification effect (providing skills needed to improve employment chances). However, participation in activation could also have a negative effect on job search, since people may search less actively while participating in such activities and this may create lock-in effects. Moreover participation in such schemes may affect the reservation requirements, e.g. by

\footnotetext{
${ }^{5}$ It could be argued that the incentive effect could be strengthened by making the activation activities demanding but meaningless. However, this would not be possible given the political constraint of decency in the treatment of people.
} 
narrowing job search to jobs very narrowly linked to the type of training received during activation.

The activation instrument has been extensively used since the policy reform made it an obligation to offer such an activation at a pre-determined timing, cf. above. The volume of activation has also been affected by the shortening of the "passive" unemployment benefit period which implied a forward move of the stock of people to be offered activation. Denmark has thus in international comparison used a substantial amount of resources on active labour market policies, cf. Figure 7. Expenses to active measures thus amount to about 1.5\% of GDP and total labour market expenses peaked at almost 7\% of GDP in 1993.

\section{Figure 7: Expenses for labour market programmes Share of GDP}

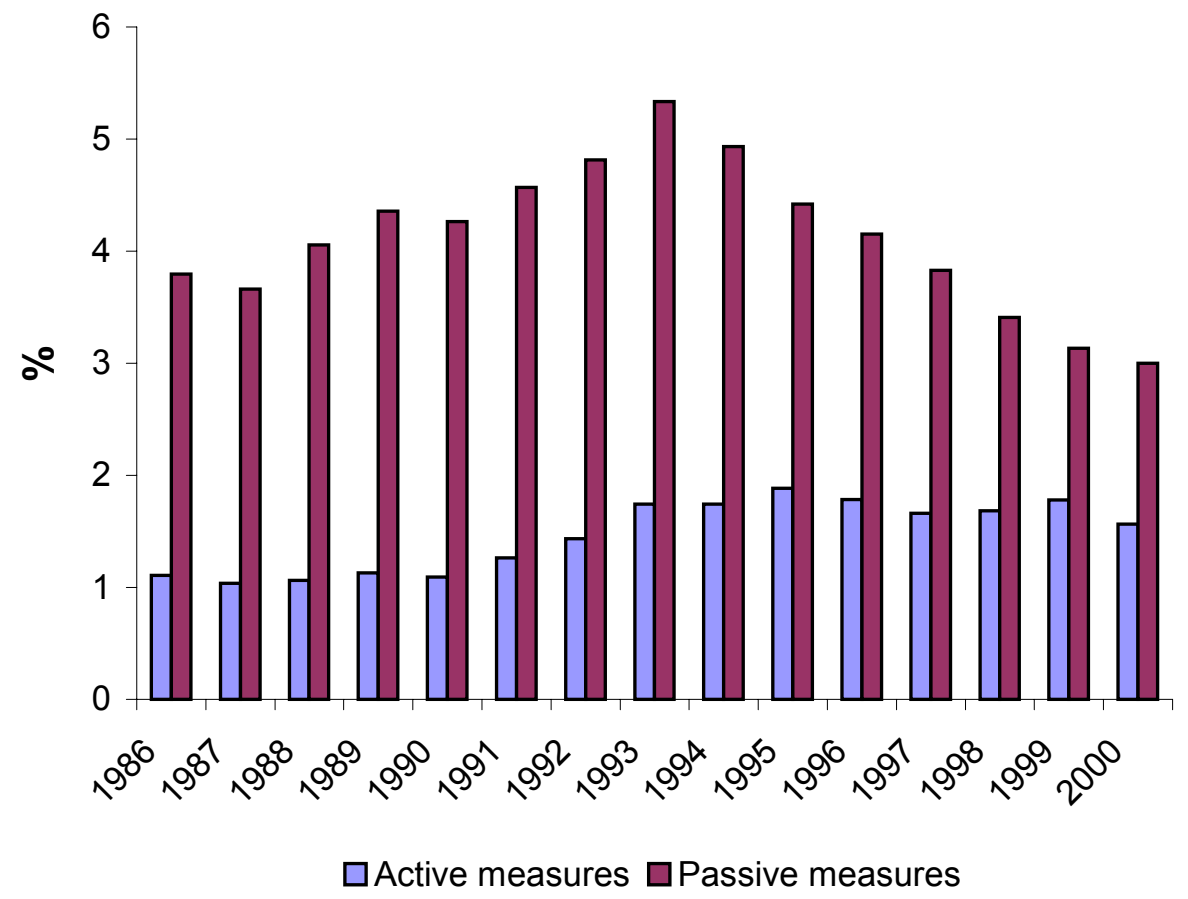

Note: Passive measures include expenses to unemployment benefits. Active measures include administrative expenses. Source: OECD (2002)

The types of activation used basically fall in three categories: private job offers, public job offers and educational activities. On average less than $10 \%$ of those in activation have been in private jobs offers, between 15 and $20 \%$ in public job offers and the remaining in various forms of educational and training activation. A number of analyses have recently been made of the effects of these various activation schemes (for an overview see Economic Council 2002). There is evidence in support of some motivation effect (the sorting effect is difficult to analyse empirically). However, for those being actually activated the improvements in labour market prospects are very small or even negative. Private job training in general improves job market prospects if employment can be gained at the workplace in which activation is taking place, but outside the specific firm this form of activation does not seem to improve labour market 
prospects. Public job training has been found to have a substantial lock-in effect, and no or even a negative qualification effect (possibly by affecting the reservation demands of unemployed). Educational activities have therefore implied some improvement in qualifications for women, skilled and old workers, but are also characterized by substantial lock-in effects.

The dismissal effects of activation can have several causes. First, given the increased emphasis on activation and the forward shift in activation the system has been overloaded and "quantity" may have come to dominate "quality", i.e. activation has become a routine and not a genuine attempt to identify the adequate activation for each single person. Second, although the empirical methods are designed so as to take account for sorting problems, it may empirically be difficult to fully control for sorting mechanisms working before the mandatory activation period is initiated, i.e. if those ending up in activation do so because they have low qualifications it is less surprising that their labour market prospects are also weak after activation.

Another issue is the way in which the activation policies, and in particular educational activities have been implemented. Problems of low labour market qualification are unlikely to be solved by participation in education activities for which almost $40 \%$ have a duration of maximum 8 weeks. In net terms the activation scheme as it has been implemented offers relatively little value for money, and there is thus a need to reform the activation system (see Det Økonomiske Råd (2002)).

\section{Wage formation}

The most visible indication that structural changes have taken place during the 1990s is the fact that unemployment has been reduced substantially without inducing a wage hike, cf. Figure 1. Accordingly, all macro-wage models have had difficulties in explaining wage developments during the latter part of the 1990s and they all predict wage increases in excess of what has been actually observed. Figure 8 shows this for a simple Phillips-curve, but the wage equations used in macroeconomic forecasting ${ }^{6}$ (see Det Økonomiske Råd (2002)) all share this feature.

Re-estimations extending the sample period thus tend to imply a reduction in the sensitivity of wages to unemployment, which is paradoxical since it should be expected that structural reforms would have implied the opposite. This finding may be the result of missing structural variables in such macro-wage equations, and thus a transitional phenomenon in a sample period in which wage increases are moderate and unemployment falling due to structural changes in the labour market. In recent work (Det Økonomiske Råd (2002)) it has been shown that a wage equation where the registered unemployment rate is replaced by an unemployment measure more directly related to the number of people actively searching for jobs (and also foreign wages), does a much better job in accounting for the wage developments. Importantly, this wage equation implies that passive measures withdrawing unemployed from active search will have detrimental effects on employment in the long run.

\footnotetext{
${ }^{6}$ This includes the wage equations in the ADAM model used by the ministry of finance, the MONA model used in the central bank, and the SMEC model used by the Economic Council.
} 
Figure 8: Actual and estimated wage increases

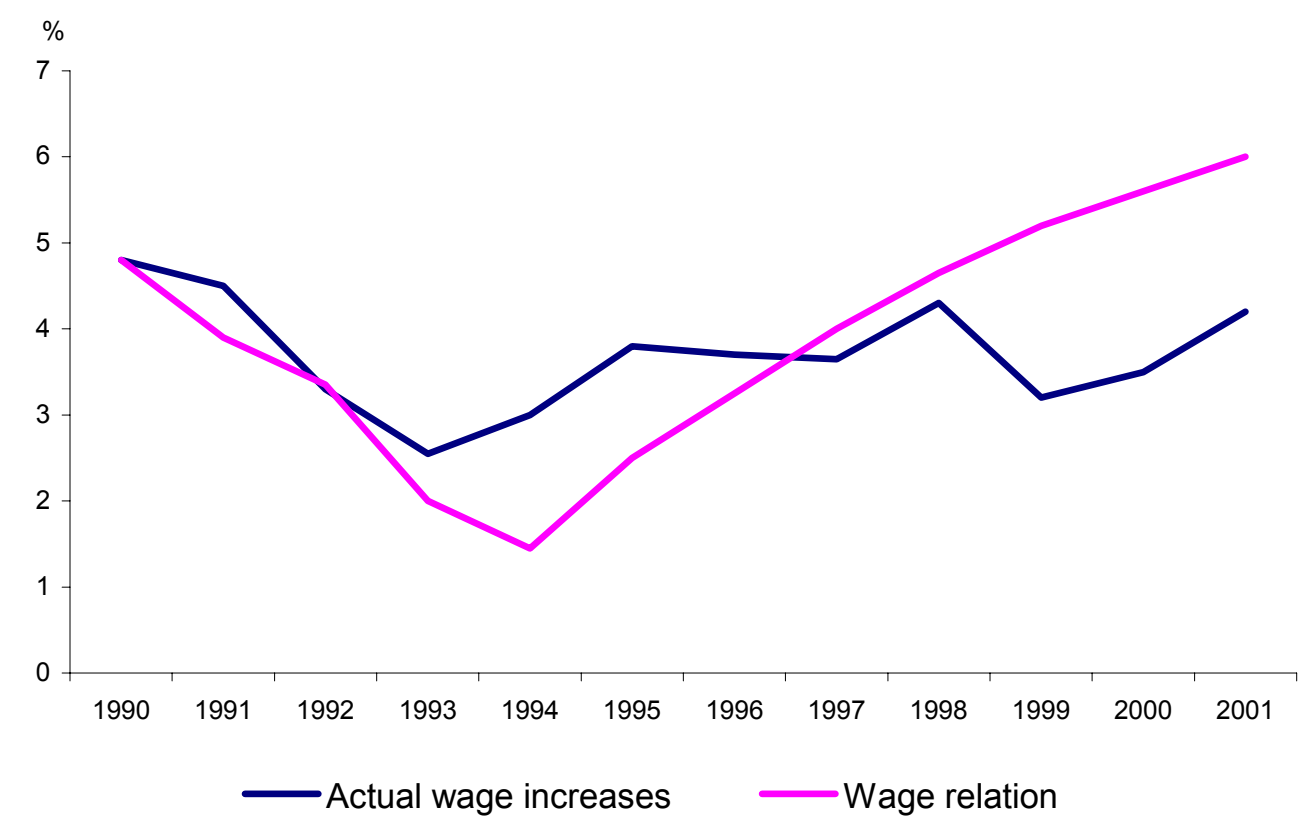

Note: The wage relation is a traditional Phillips curve estimated for the period 1960 to 2001 Source: Own estimates

\subsection{Decentralization}

The Danish labour market is well organized (more than $70 \%$ of the work force is a member of a trade union) and traditionally the labour market has been fairly centralized.

The 1990s has also seen important changes in the institutional structure of the labour market with a shift from centralized towards more decentralized bargaining structures. Boeri et al. (2001) report an index ${ }^{7}$ for centralization/coordination of the bargaining system taking both horizontal and vertical elements into account and find that it for Denmark has dropped from 0.64 for the period 1973-77, to 0.47 for 1983-87 and 0.34 for 1993-97.

The developments in the Danish labour market during the 1990s are, however, a challenge to the literature on the relation between centralization/decentralization and labour market performance (for a survey and references see Boeri et al. (2001)). According to the centralization index Denmark was ranked 4 in the 1970s and ranked 9 in the 1990s for the 15 countries included in the study. Hence, Denmark has moved from centralized/coordinated bargaining to an intermediate position. According to empirical estimates reported in Boeri et al. (2001) this should imply an increase in the unemployment rate between 3.4 and 6.8 percentage points. If Denmark instead is interpreted as moving from an intermediate position to low centralization/ coordination, the unemployment effect should be in the interval spanned by an increase of 3.2 percentage points and a decrease of 1.9 percentage points. Even this interpretation leaves some margin to the actual change in unemployment.

A further puzzle in recent developments is that decentralization of wage formation should be expected to enhance the sensitivity of wages to short-run fluctuations in activity, but empirical evidence shows that this has not been the case, cf. above. One explanation may be that the

\footnotetext{
${ }^{7}$ Defined to belong to the unit interval. A value of 1 corresponds to fully centralized and 0 to fully decentralized bargaining.
} 
simultaneous shift in labour market policies has reduced the outside option of workers, and therefore induced wage moderation, cf. e.g. Figure 6. Empirically, it is difficult to distinguish this trend shift in market power from the change in cyclical sensitivity over a short sample period

With the increased decentralization of wage formation it is natural that there has been changes in wage systems in the labour market in the sense that more workers are now employed under a wage system allowing local and individual variations in wages and less workers are employed under the traditional wage system implying a centrally stipulated wage. The traditional wage system in Denmark has been the so-called standard pay system ("normallønssystem"), which fixes the wage for different categories of workers in the labour market for the contract period (usually two years). Historically, this system has dominated the labour market for unskilled workers. Various other wage systems ${ }^{8}$ allow for a larger decentralized element in wage formation which either make room for personal allowances related to observable facts like job functions, experience, qualifications etc. or leaves the wage for local negotiation between the employer and employee subject to some minimum levels. Table 2 shows the development in the use of the various wage systems during the 1990s and there is a clear trend towards the use of wage systems allowing for more flexible and decentralized wage determination. Note that central (sector) bargaining still determines the wage for workers on the standard wage contract. In the past there has also been some local elements in wage determination showing up in the form of wage drift.

Table 2: Wage systems in the Danish labour market

\begin{tabular}{|l|c|c|c|c|c|c|}
\hline $\begin{array}{l}\text { Contract } \\
\text { form }\end{array}$ & 1989 & 1991 & 1993 & 1995 & 1997 & 2000 \\
\hline $\begin{array}{l}\text { Standard } \\
\text { wage }\end{array}$ & 34 & 19 & 16 & 16 & 16 & 15 \\
\hline $\begin{array}{l}\text { Wage } \\
\text { systems } \\
\text { with } \\
\text { decentraliz } \\
\text { ed wage } \\
\text { setting }\end{array}$ & 66 & 81 & 84 & 84 & 84 & 85 \\
\hline $\begin{array}{l}\text { Sum } \\
\text { Note: Wage systems with decentralized wage setting include: "normallønssystemet", "minimalsystemet" og "uden lonsats" } \\
\text { Source: Dansk Arbejdsgiverforening (2002) }\end{array}$ & & & &
\end{tabular}

Another noteworthy feature of the development during the 1990s is an increase in wage dispersion for workers with job functions at a high and intermediate level within firms, and also within business services, while no increases in wage dispersion have been observed among ordinary workers, cf. Figure 2.

\footnotetext{
${ }^{8}$ The two major systems are the standard pay system ("normallønsområdet") and the minimum wage system ("minimallønssystemet"). Note that the latter is not to be confused with the minimum wage. The minimum wage is determined through negotiation and gives an absolute floor below for wage determination.
} 


\section{Figure 8: Wage dispersion for job \\ functions: Denmark 1993-2000}

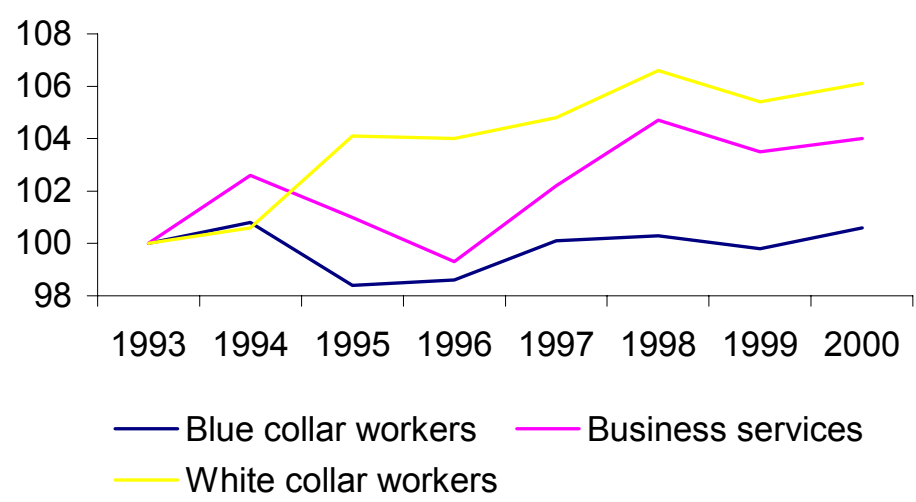

Source: Dansk Arbejdsgiverforening (2001)

With a move from centralized towards a more decentralized system of wage determination it is natural to expect that firm specific factors come to play a larger role for wage formation. The Danish labour market has historically been characterized by a fairly equal wage distribution, and therefore firm specific factors have previously played a minor role (although variation across firms have existed). Bingley and Westergaard-Nielsen (2002) include tenure among standard explanatory variables in estimations of individual (annual) wage equations, and use the estimated coefficient to construct a measure of the return-to-firm specific human capital. While the return-to-firm specific human capital is moderate, it is found that it has been increasing in recent years ${ }^{9}$. One interpretation is that this is the outcome of the decentralization process making it possible for firms to use wage incentives to protect investments in firmspecific human capital

Another indirect approach by which to assess the importance of decentralization of wage formation is to exploit that wage formation is affected differently by taxation depending on whether the market is competitive or imperfectly competitive. While average taxes unambiguously increase wages under imperfect competition, they have an ambiguous effect in competitive markets (income vs. substitution effects). Marginal taxes would under standard assumptions increase wage demands in competitive markets and reduce them in imperfectly competitive markets. Using this insight Pedersen and Smith (1999) and Pedersen, Rasmussen and Clemmensen (2002) study wage formation for various groups in the labour market taking explicit account of the more decentralized wage formation by allowing a larger role for individual effects on wages. Interestingly, they find that a sample including the first part of the 1990s tends to yield results on the effects of taxation more in line with competitive models, relatively to earlier studies. They take this as evidence that wage formation effectively has become more decentralized.

In sum, wage formation has become more decentralized, but the Danish experience during the 1990s cannot simply be explained by decentralization of wage formation. This does not mean that decentralization is unimportant, but that it may be interacting with other important changes.

\footnotetext{
${ }^{9}$ Though still firm-specific returns play a less important role than in e.g. the US.
} 


\subsection{Mis-match}

The extent to which aggregate unemployment is driven by mismatches along dimensions like qualification and geography is usually addressed by considered so-called Beveridge curves. However, vacancy data for Denmark are of poor quality, but based on data from business surveys there is an indication that mis-match problems increased during the 1970s and 1980s since there was an increase in both vacancies and unemployment, cf. Figure 10. Judged from these data it also seems that mis-match problems have been reduced during the 1990s.

\section{Figure 10: Vacancies and unemployment}

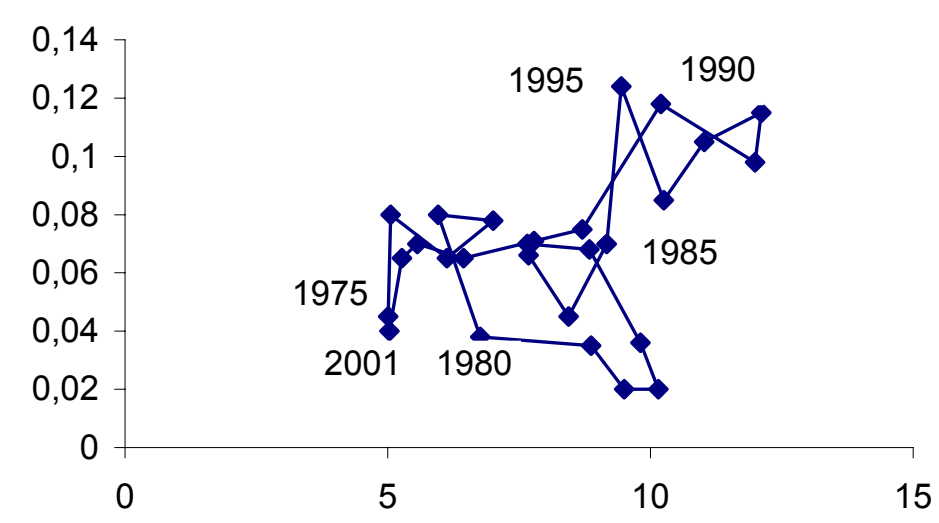

Note: Vacancies from survey data as 0.5 (proportion of firms reporting shortage of skilled workers + proportion for firms reporting shortage of other labour.

Source: Danmarks Statistik

Both skill and geographical aspects seem to have been of importance for mis-match problems in the labour market. Despite a period with high overall unemployment there has been substantial differences in unemployment across skill groups. In particular it does not seem that skill differences are lower currently than under the high unemployment period. Regular differences in unemployment rates for various skill groups are thus no smaller today than in the early 1990s, and if anything it has tended to increase.

There is also evidence that shifts in relative labour demand have been skill-biased to the favour of highly skilled. Fosgerau et al. (2001) find the relative demand shift (skilled relative to unskilled) over the period 1980-98 to have been above 4\%. Still the relative wage structure between skilled and unskilled has remained practically unchanged (the ratio of unskilled wages to the average was $90 \%$ in 1980 and $89.4 \%$ in 1998), and the unemployment rate for unskilled has not increased either. Hence, although the skill-bias has been as large in Denmark as in many other countries, the consequences have been less dramatic since the relative shift in the skill composition of labour demand has been matched by an almost identical change in the skill composition of labour supply (see Fosgerau et al. (2001)).

Whereas there are substantial differences in unemployment rates across geographical areas (in 2001 the unemployment rate across counties varied between 3 and 7\%), various analyses have 
found difficulties in relating geographical mobility to economic variables. Hence, mobility does not seem to play an important role in eliminating geographical differences in unemployment. Even disaggregating at skill levels there is no indication that geographical differences have been reduced during the recent period with falling unemployment (Det Økonomiske Råd, 2002).

In the international debate it has been proposed that housing may be an impediment to mobility and therefore contribute to persistent unemployment problems(see Oswald (1996)). However, since the share of home owners is high (above $50 \%$ ), Denmark should be a country where housing is found to contribute to a high unemployment rate. However, empirical studies fail to find support for this hypothesis, if anything home-owners seem to return more quickly to work than others. Though, it is the case that home-owners tend to be less geographically mobile than tenants. This could be interpreted as evidence either of a sorting effect of entrance into home ownership or the fact that home owners more quickly lower their reservation demands due to their financial obligations.

\subsection{Taxation}

The average tax burden in Denmark is high (in $200155 \%$ of GDP), and the tax structure is such that the bulk of revenue accrues from direct income taxation and indirect taxes (VAT). The total tax wedge on labour income may be a better indicator than the gross tax burden for the effects of taxation for the labour market. For an average worker the tax wedge is $60 \%$, which is among the highest in Europe (Skatteministeriet (2002)). Progressive elements in the taxation system imply that the tax burden is increasing in income. A recurrent theme has been the disincentive effects of taxation for the labour market. This issue is complicated since the effects depend both on the institutional structure of the labour market as well as possibly counteracting substitution and income effects. In recent years focus has been on the possibility of reducing marginal tax rates on labour income with the aim of improving incentives for work including mobility in all its dimensions.

Since about $40 \%$ of full time employed pay the top marginal tax rate, it has been a concern for tax reforms how to reduce marginal tax rates. A number of tax reforms have taken place in recent years, aiming at broadening the tax base and reducing marginal tax rates on labour income. Table 3 summarizes the development in marginal tax rates, and it is seen that marginal tax rates have been reduced, but they are still high.

Table 3 Marginal tax-rates - Personal Income

\begin{tabular}{|l|l|l|l|l|}
\hline Income level (b) & 1986 & 1993 & 1998 (a) & 2002 (a) \\
\hline Low & 48.0 & 50.6 & 45.2 & 44.2 \\
\hline Medium & 62.4 & 58.2 & 50.7 & 49.7 \\
\hline High & 73.2 & 68.7 & 62.0 & 63.3 \\
\hline
\end{tabular}

Notes: a) Inclusive labour market contributions, b) Income level is defined for the income levels applying to payment of "bundskat", "mellemskat" and "topskat". For 2002 Low income would apply for incomes below DKK 191.200, and high income for incomes above 285.200.

Source: Andersen et al. 2001.

A number of recent empirical studies have considered the determinants of labour supply. It is in general found that the income effect is negative, and the substitution effect positive. While the income effect is approximately equal for men and women, the substitution elasticity (both the compensated and the uncompensated) is larger for women than men by factor 2 to 3 . Given this it is possible within the existing tax system to propose tax reforms which would increase 
labour supply and have a non-trivial self-financing element (see e.g. Frederiksen and Hansen (2002) and the references therein).

Taxation and in particular marginal taxes may affect the labour market through other routes than the quantity of labour supply. High marginal taxes may reduce the incentive for mobility both across the geographical and the skill dimension, since the private return of such mobility is reduced. Moreover taxation may affect wage formation and lead to higher wages. This relation may depend critically on the institutional arrangements concerning wage formation, since centralized wage setting institutions may internalise tax externalities (see Summers et al. (1993)). However, this would not be the case in a labour market with a more decentralized system of wage formation. Since Denmark has moved from a fairly centralized to a more decentralized system of wage formation (see above) this suggests that the distortionary consequences of taxation on wage formation may increase. Empirical evidence already indicates that such a change is taking place (see Pedersen et al. (2002)).

The need for tax reform is thus a recurrent theme, and the possibility of shifting some of the tax burden from labour to internationally less mobile tax objects like houses and natural resources is often debated.

\section{Labour shortage?}

Demographic changes are also going to affect the Danish labour market. Figure 11 shows the relation between the number of people aged 62 or above relative to those between 17 and 61 , and it is seen that the demographic changes are fairly substantial within the next 30 years. Recent projections suggest that the labour supply would be reduced by about $2.5 \%$ from 2000 to 2010 as a result of demographic changes. At the same time there are a number of strong trends reducing labour supply, namely, the trend decline in working hours (over the week and the year), lower labour market participation for prime age groups and early retirement. The early retirement problem is particularly problematic since it is induced by a scheme subsidizing early retirement. Although the scheme was originally intended to provide an escape route for those who for physical or mental reasons have difficulty in having an ordinary job, it has become quite popular for large groups in the labour market as a means to enjoy more leisure, i.e. early retirement has become a welfare item. Recent analysis shows that 7 out of 10 in the scheme enter from regular work, and that 8 out of 10 have chosen early retirement voluntarily. The number of persons in the scheme by 2002 amounts to more than $5 \%$ of the labour force. The popularity of the scheme has made it difficult to reform, although there was a minor reform in 1998. 
Figure 11: Demographic shifts:

Age group 62+ relative to age group 17-61

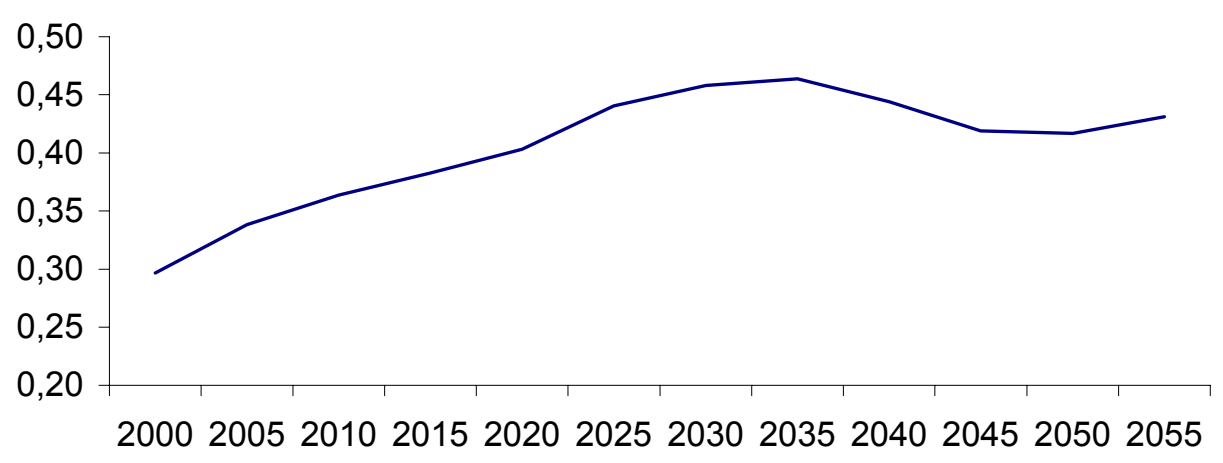

Source: Det Økonomiske Råd (Autumn 2002)

The demographic changes thus pose a challenge to the labour market, and there has been wide concern that shortage of labour would arise, which in turn would make it difficult to maintain wage developments on a path consistent with the overall macroeconomic policy strategy. A further challenge arises from the fact that the demographic shifts have substantial consequences for public finances given the way the Danish welfare model is organized. Various projections have been made indicating that public financed would be significantly affected if current standards and systems are to be maintained (Finansministeriet (2002a), Det Økonomiske Råd (2002), L.H. Pedersen (2002)).

Another key issue in the Danish labour market is the poor integration of immigrants For men the labour force participation rate is about 20 percentage points lower than that of Danes, and for women it is close to 40 percentage points lower (P. Pedersen (2002)). However, analysis have documented that when controlling the labour force participation for various background variables, it is found that the difference in labour force participation mainly can be attributed to lower average qualifications for immigrants (Det Økonomiske Råd (2002)). Accordingly, improved labour market integration would have to go via more education, training etc., which raises new demands for labour market policy.

\section{Concluding remarks}

The labour market developments in Denmark during the 1990s have been unique seen relative to the historic experience. This development cannot only be attributed to favourable macroeconomic conditions and a successful stabilization policy. Important institutional changes as well as structural policies have played an important role.

The Danish labour market is adapting to a number of international trends including the consequences of technological developments and international integration. A skill-bias in labour demand have had quantitatively strong effects also on the Danish labour market but the consequences have been less visible since it has been accompanied by a quantitatively similar change in relative labour supply. The latter can partly be attributed to passive measures reducing labour supply, and the fact that a larger share of young generations have labour market relevant qualifications. International integration may make employment more sensitive to wages as well as changing the outside options determining bargaining power in the labour market. These effects are more difficult to identify empirically but the changes in wage 
formation and the more decentralized wage setting institutions can be interpreted as a response to the challenges arising from international integration.

The unique Danish aspect has been how to combine extended welfare arrangements with an incentive structure in the labour market which does not induce rigidities and persistent high unemployment. Whereas policies in the past have been passive in nature with focus on income maintenance a number of reforms during the 1990s lead to a more active approach. While grossly respecting the political constraint that transfer incomes could not be reduced, they changed the incentive structure by reducing the possibilities for passively claiming benefits (stricter eligibility rules, short benefit periods etc.), and via the so-called activation policies obligations were attached to claiming unemployment and social benefits. It is very difficult to precisely quantify the contribution of the many elements in the policy reforms, but in an overall assessment there is no doubt that labour market structures have been changed, and this is an important reason for the large reduction in unemployment. However, business cycle developments have also played a role.

Despite the reforms undertaken incentive problems remain. In a forward-looking perspective an important objective would be to increase the labour force participation (to counteract the effects of demographic shifts, and reduce the burden hereof for public finances) along especially two dimensions, namely, better integration of immigrants into the labour market and by creating incentives for latter retirement (where the current policies give an incentive to early retirement). Since especially the former involves groups which hitherto have had a more marginal attachment to the labour market the challenge is large. As regards early retirement the political constraints are also very tight since the early retirement scheme has become a very popular scheme. Finally, the overall tax burden and the structure of taxation may become an increasingly important issue in the future. By international standards the tax burden and marginal taxes are high, and it is a very open question to what extent this situation is robust to further international integration.

\section{References:}

Andersen, T.M., 1994, Disinflationary Stabilization Policy - Denmark in the 1980s, In J. Åkerhold and A. Giovannini (eds.) Exchange Rate Policies in the Nordic Countires, CEPR.

Andersen, T.M, 2002, Product Market Integration, Wage Dispersion and Unemployment, Working paper.

Andersen, T.M., and S. Hylleberg, 2000, Source of Persistence in employment adjustment, Oxford Economic Papers, 52, 72-95.

Andersen, T.M., B. Dallum, H. Linderoth, V. Smith and N. Westergård-Nielsen, 2001, The Danish Economy - An International Perspective. DJØF Publishing Copenhagen.

Arbejdsministeriet, 2000, Effekter af aktiveringsindsatsen.

Beskæftigelsesministeriet, 2002, Flere i arbejde.

Bingley, P., and N. Westergaard-Nielsen, 2002, Tenure and Firm-Specific Capital, Unpublished Working Paper. 
Bocian, S., J. Nielsen, and J. Smidt, 1999, SMEC - Modelbeskrivelse og egenskaber, Working paper 99:7 Economic Council Secretariate.

Boeri, T., A. Brugiavini and L. Calmfors (eds.), 2001, The Role of Unions in the Twenty-First Century, Oxford University Press.

Dansk Arbejdsgiverforening, 2001, Arbejdsmarkedsrapport 2001 (www.da.dk)

Dansk Arbejdsgiverforening, 2002, Arbejdsmarkedsrapport 2002 (www.da.dk)

Det Økonomiske Råd, 2001, Dansk Økonomi Efteråret 2001 (www.dors.dk)

Det Økonomiske Råd, 2002, Dansk Økonomi Efteråret 2002 (www.dors.dk)

Finansministeriet, 1999, Finansredegørelsen 98/99 (www.fm.dk)

Finansministeriet, 2000, Finansredegørelsen 2000 ( $\underline{\text { www.fm.dk }}$ )

Finansministeriet, 2002, Finansredegørelsen 2002 (www.fm.dk)

Finansministeriet, 2002, Fordeling og Incitamenter.

Fosgerau, M., S.E.H. Jensen and A. Sørensen, 2001, Relative Demand Shifts for Educated Labour, CEBR Discussion Paper no 2000-11.

Madsen, J.S., S.K. Andersen and J. Due, 2001, Fra centraliseret decentralisering til multiniveau regulering - Dansk arbejdsmarkedsrelation mellem kontinuitet og forandring. Faos Working Paper 032.

Nicoletti, G., S. Scarpetta and O. Boylaud, 2000. Summary of Indicators of Product Market Regulation with an Extension of Employment Protection Legislation, OECD Economics Department, Working Paper 226.

Oswald, A.J., 1996, A Conjecture on the Explanation for High Unemployment in Industrialized Nations: Part I, Working Paper, University of Warwick.

OECD, 2002, Employment Outlook.

Parsons, D.O., T. Tranæs and H.B. Lilleør, 2002, Voluntary Public Unemployment Insurance, Working Paper.

Pedersen, L.H., 2002, Befolkningsudvikling, integration og økonomiske politik, Danish Rational Economic Agents Model, DREAM. (www.dream.dk)

Pedersen, L.H, J.H. Rasmussen and K. Clemmensen, 2002, Individual Wage Formation and Minimum Wages: Theoretical and Empirical Effects of Progressive Taxation, Unpublished Working Paper. 
Pedersen, L.H., and N. Smith, 1999, Minimum Wage Contracts and Individual Wage Formation: Theory and Evidence from Danish Panel Data, Ch 6 in Andersen, T. M., S.E. Hougård-Jensen and $\mathrm{O}$. Risager, Macroeconomic Perspectives on the Danish Economy, MacMillan.

Pedersen, P.J. 2002, Arbejdsmarkedsintegration, arbejdsmarkedspolitik og overførselsindkomster - forskningsmæssig viden om immigration fra mindre udviklede lande siden 1980, AMID Working Paper 7/2002

Pedersen, P.J. og N Smith., 2002, Unemployment Traps: Do Financial Disincentives Matter? European Sociological Review, Vol. 18, No. 3, 271-288.

Skatteministeriet, 2002, Skat - Beskatning af arbejdskraft, December 2002.

Summers, L., J. Gruber and R. Vegara, 1993, Taxation and the Structure of Labor Markets: The Case of Corporatism, Quarterly Journal of Economics, 385-411. 


\title{
CESifo Working Paper Series
}

\author{
(for full list see www.cesifo.de)
}

866 Ernst Fehr, Urs Fischbacher, Bernhard von Rosenbladt, Jürgen Schupp, and Gert G. Wagner, A Nation-Wide Laboratory. Examining Trust and Trustworthiness by Integrating Behavioral Experiments into Representative Survey, February 2003

867 Frank Heinemann, The Inflationary Impact of Wage Indexation, February 2003

868 Eytan Sheshinski, Bounded Rationality and Socially Optimal Limits on Choice in a Self-Selection Model, February 2003

869 M. Hashem Pesaran, Estimation and Inference in Large Heterogenous Panels with Cross Section Dependence, February 2003

870 Luis H. R. Alvarez and Erkki Koskela, On the Tree-Cutting Problem under Interest Rate and Forest Value Uncertainty, February 2003

871 Norbert Berthold and Rainer Fehn, Unemployment in Germany: Reasons and Remedies, February 2003

872 Clemens Fuest, Bernd Huber, and Philipp Tilleßen, Tax Policy and Entrepreneurship in the Presence of Asymmetric Information in Capital Markets, February 2003

873 Eytan Sheshinski, Optimum and Risk-Class Pricing of Annuities, February 2003

874 Willi Leibfritz, Paul O'Brien and Jean-Christophe Dumont, Effects of Immigration on Labour Markets and Government Budgets - An Overview, February 2003

875 M. Hashem Pesaran and Allan Timmermann, How Costly is it to Ignore Breaks when Forecasting the Direction of a Time Series?, February 2003

876 Thorvaldur Gylfason and Gylfi Zoega, Education, Social Equality and Economic Growth: A View of the Landscape, February 2003

877 Robin Boadway and Jean-François Tremblay, Public Economics and Startup Entrepreneurs, February 2003

878 Erkki Koskela and Roope Uusitalo, The Un-Intended Convergence: How the Finnish Unemployment Reached the European Level, February 2003

879 Robert Fenge and Volker Meier, Pensions and Fertility Incentives, February 2003

880 Eytan Sheshinski, Note on Income Taxation and Occupational Choice, February 2003

881 A B Atkinson, Income Inequality in OECD Countries: Data and Explanations, February 2003 
882 Thomas Gehrig and Rune Stenbacka, Venture Cycles: Theory and Evidence, February 2003

883 Ralf Becker and Thomas Hellmann, The Genesis of Venture Capital - Lessons from the German Experience, March 2003

884 Eytan Sheshinski, Note on the Optimum Pricing of Annuities, March 2003

885 Paul De Grauwe and Magdalena Polan, Globalisation and Social Spending, March 2003

886 F. van der Ploeg, Do Social Policies Harm Employment and Growth?, March 2003

887 Mirjam van Praag, Initial Capital Constraints Hinder Entrepreneurial Venture Performance: An empirical analysis, March 2003

888 Bernard Steunenberg, Coordinating Sectoral Policymaking: Searching for Countervailing Mechanisms in the EU Legislative Process, March 2003

889 Eytan Sheshinski, Optimum Delayed Retirement Credit, March 2003

890 Frederick van der Ploeg, Rolling Back the Public Sector - Differential effects on employment, investment and growth, March 2003

891 Paul De Grauwe and Marc-Alexandre Sénégas, Monetary Policy in EMU when the Transmission is Asymmetric and Uncertain, March 2003

892 Steffen Huck and Kai A. Konrad, Strategic Trade Policy and the Home Bias in Firm Ownership Structure, March 2003

893 Harry Flam, Turkey and the EU: Politics and Economics of Accession, March 2003

894 Mathias Hoffmann and Ronald MacDonald, A Re-examination of the Link between Real Exchange Rates and Real Interest Rate Differentials, March 2003

895 Badi H. Baltagi, Espen Bratberg, and Tor Helge Holmås, A Panel Data Study of Physicians' Labor Supply: The Case of Norway, March 2003

896 Dennis C. Mueller, Rights and Citizenship in the European Union, March 2003

897 Jeremy Edwards, Gains from Trade in Tax Revenue and the Efficiency Case for Trade Taxes, March 2003

898 Rainer Fehn and Thomas Fuchs, Capital Market Institutions and Venture Capital: Do They Affect Unemployment and Labour Demand?, March 2003

899 Ronald MacDonald and Cezary Wójcik, Catching Up: The Role of Demand, Supply and Regulated Price Effects on the Real Exchange Rates of Four Accession Countries, March 2003 
900 R. Selten, M. Schreckenberg, T. Pitz, T. Chmura, and S. Kube, Experiments and Simulations on Day-to-Day Route Choice-Behaviour, April 2003

901 Stergios Skaperdas, Restraining the Genuine Homo Economicus: Why the Economy Cannot be Divorced from its Governance, April 2003

902 Yin-Wong Cheung, Menzie D. Chinn, and Antonio Garcia Pascual, What Do We Know about Recent Exchange Rate Models? In-Sample Fit and Out-of-Sample Performance Evaluated, April 2003

903 Mika Widgrén, Enlargements and the Principles of Designing EU - Decision-Making Procedures, April 2003

904 Phornchanok Cumperayot, Dusting off the Perception of Risk and Returns in FOREX Markets, April 2003

905 Kai A Konrad, Inverse Campaigning, April 2003

906 Lars P. Feld and Stefan Voigt, Economic Growth and Judicial Independence: Cross Country Evidence Using a New Set of Indicators, April 2003

907 Giuseppe Bertola and Pietro Garibaldi, The Structure and History of Italian Unemployment, April 2003

908 Robert A.J. Dur and Otto H. Swank, Producing and Manipulating Information, April 2003

909 Christian Gollier, Collective Risk-Taking Decisions with Heterogeneous Beliefs, April 2003

910 Alexander F Wagner, Mathias Dufour, and Friedrich Schneider, Satisfaction not Guaranteed - Institutions and Satisfaction with Democracy in Western Europe, April 2003

911 Ngo Van Long, Raymond Riezman, and Antoine Soubeyran, Trade, Wage Gaps, and Specific Human Capital Accumulation, April 2003

912 Andrea Goldstein, Privatization in Italy 1993-2002: Goals, Institutions, Outcomes, and Outstanding Issues, April 2003

913 Rajshri Jayaraman and Mandar Oak, The Signaling Role of Municipal Currencies in Local Development, April 2003

914 Volker Grossmann, Managerial Job Assignment and Imperfect Competition in Asymmetric Equilibrium, April 2003

915 Christian Gollier and Richard Zeckhauser, Collective Investment Decision Making with Heterogeneous Time Preferences, April 2003

916 Thomas Moutos and William Scarth, Some Macroeconomic Consequences of Basic Income and Employment Subsidies, April 2003 
917 Jan C. van Ours, Has the Dutch Miracle Come to an End?, April 2003

918 Bertil Holmlund, The Rise and Fall of Swedish Unemployment, April 2003

919 Bernd Huber and Marco Runkel, Optimal Design of Intergovernmental Grants under Asymmetric Information, April 2003

920 Klaus Wälde, Endogenous Business Cycles and Growth, April 2003

921 Ramon Castillo and Stergios Skaperdas, All in the Family or Public? Law and Appropriative Costs as Determinants of Ownership Structure, April 2003

922 Peter Fredriksson and Bertil Holmlund, Improving Incentives in Unemployment Insurance: A Review of Recent Research, April 2003

923 Bernard M.S. van Praag and Adam S. Booij, Risk Aversion and the Subjective Time Discount Rate: A Joint Approach, April 2003

924 Yin-Wong Cheung, Kon S. Lai, and Michael Bergman, Dissecting the PPP Puzzle: The Unconventional Roles of Nominal Exchange Rate and Price Adjustment, April 2003

925 Ugo Trivellato and Anna Giraldo, Assessing the 'Choosiness' of Job Seekers. An Exploratory Approach and Evidence for Italy, April 2003

926 Rudi Dornbusch and Stanley Fischer, International Financial Crises, April 2003

927 David-Jan Jansen and Jakob de Haan, Statements of ECB Officials and their Effect on the Level and Volatility of the Euro-Dollar Exchange Rate, April 2003

928 Mario Jametti and Thomas von Ungern-Sternberg, Assessing the Efficiency of an Insurance Provider - A Measurement Error Approach, April 2003

929 Paolo M. Panteghini and Guttorm Schjelderup, Competing for Foreign Direct Investments: A Real Options Approach, April 2003

930 Ansgar Belke, Rainer Fehn, and Neil Foster, Does Venture Capital Investment Spur Employment Growth?, April 2003

931 Assar Lindbeck, Sten Nyberg, and Jörgen W. Weibull, Social Norms and Welfare State Dynamics, April 2003

932 Myrna Wooders and Ben Zissimos, Hotelling Tax Competition, April 2003

933 Torben M. Andersen, From Excess to Shortage - Recent Developments in the Danish Labour Market, April 2003 